\title{
Where have all the Bilneys gone?
}

\section{As with nuclear testing controversies, we should not shy away from advocating on climate change}

did not go to Gordon Bilney's funeral. But then why should I be invited? At one time we inhabited different sides of the political divide - although in our case the divide was often razor thin.

Bilney was Minister for Development Cooperation and Pacific Island Affairs in the Keating government from 1993 to 1996. Before that, in the early 1960s, I always greatly admired him as a fellow student politician, when we were all radicals. Conscious of "the Bomb" then, we had considerable sympathy for the Campaign for Nuclear Disarmament and the daguerreotype grainy images of endless duffle coats and miserable faces of protesters marching from London to the Aldermaston Atomic Weapons Research Establishment. However, the push for a nuclear-powered Australia was secondary for Australian youth as Australia was increasingly sucked into the conflict in Vietnam.

When I was a Victorian medical student, Bilney was a South Australian dental student. He went from teeth pulling to jawboning, entering the world of diplomacy, which readied him for politics when he became the federal member for Kingston in South Australia and served five terms from 1983.

For a brief period in the nineties, Bilney contributed significantly to public health. The 1996 federal election came, and unfortunately, Bilney went — not only as a government Minister, but also from his electorate - a casualty of an electoral intercession Australia "had to have".

At the time Bilney was Minister, I was President of the Australasian Faculty of Public Health Medicine (AFPHM), a faculty of the Royal Australasian College of Physicians (RACP). There was a strong push - led by Sue Morey, who had been to Papua New Guinea in the 1960s and 1970s - for public health physicians to be more involved with the South Pacific nations. As a result of her legacy, Bilney and I renewed our relationship.

Whenever I entered his ministerial office, he would greet me with the salutation "comrade". The idea that the government could help the public health physicians bring representatives of small Pacific nations to the AFPHM annual meeting appealed to him and he supported funding for this. A number of potential initiatives came from his attendance at one of the AFPHM's meetings but, sadly, these initiatives lapsed with the change of government.

The single factor that unified most South Pacific nations was nuclear testing at the Mururoa and Fangataufa atolls. In June 1995, the then French President Jacques Chirac announced that France would conduct a nuclear test series there beginning in September 1995 - just one year before the signing of the Comprehensive Nuclear-Test-Ban Treaty — precipitating great outrage.

Having persuaded the RACP to participate, and with advertising agency Saatchi and Saatchi's considerable

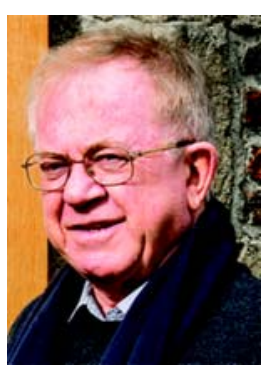

John B Best AO, MD BS, PhD, DSc(Hon), Director of Clinical Training

Murray to the Mountains Intern Training Program, Sydney, NSW.

jbbest@iimetro.com.au

doi: 10.5694/mjal3.00250

It is easy to put out a media release ... but it is another matter to set out a plan of action assistance, the AFPHM spearheaded an antinuclear-testing campaign based around full-page advertisements, not only in Australia but also in France. Le Figaro refused to run them, but both Le Monde and Libération accepted them. Sackfuls of antitesting letters arrived at both the Australian Embassy and the presidential palace in Paris.

The advertisements coincided with Bastille Day 1995, and The Australian summed up the situation by saying that France's total indifference to South Pacific feeling about nuclear tests was disgraceful. ${ }^{1}$ There were numerous protests around Australia. As a sidelight, the Australian fencing team, off to an international competition in The Hague, wore T-shirts featuring a nuclear explosion and the pointed wording "Club Med Mururoa". Despite such confrontational behaviour, the T-shirts proved very popular at the competition!

Meanwhile, in an expression of solidarity, Cook Islands doctors wrote an open letter condemning the ongoing testing, which was published in Australian newspapers - an indication that seed funding for public health interaction with our Pacific nations colleagues instituted by Bilney had stimulated a spirit of cooperation - at least in this one important public health issue.

After a sixth nuclear test in January 1996, France ended its program. We had all stirred the controversy; who knows how much had penetrated thinking at the presidential palace.

Fast-forward to the present, and public health physicians have tried to take on the problem of climate change; a particularly relevant topic for the island nations of the South Pacific, where rising sea levels are inevitable. The College has baulked.

The difference between then and now is that, although there were elements in the College then who did not want involvement in the nuclear protests, the majority realised that the college had an obligation not only to make statements but also to actively lead in areas where the health of the environment was a vital community issue. It is easy to put out a media release on a Sunday evening, but it is another matter to set out a plan of action and prosecute it without fear or favour. Presumably, climate change should loom large in such considerations. Where has the concern for our colleagues in the South Pacific and their work gone over the past two decades?

The problem is that the Bilneys of this world are a rare commodity. After the nuclear tests stopped and the Australian Government changed in 1996, Bilney went fishing. For the AFPHM now, the antinuclear stand, distant as it may be, should serve as an example for intervening in the climate change policy debate and inspire hope that there is a champion like Gordon Bilney willing to assist.

Competing interests: No relevant disclosures.

Provenance: Commissioned; not externally peer reviewed.

1 Sheridan G. France's action calls its legitimacy as a colonial power into question. The Australian 1995; $12 \mathrm{Jul}$. 